\title{
West Nile virus in the context of climate change
}

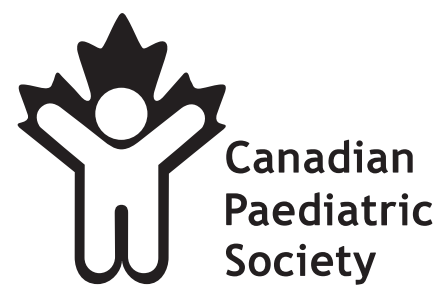

W

est Nile virus (WNV), a flavivirus maintained in the bird-mosquito transmission cycle, first arrived in Canada in the summer of 2001. In 2003, due to growing concern about the impact of WNV in Canada, the Canadian Paediatric Society issued a Paediatric Infectious Disease Note followed by an Update in 2004 (1,2). The present Paediatric Infectious Disease Note provides a further update on WNV.

WNV is now known to infect a wide range of birds, with secondary transmission to many mammals as well as humans in Canada $(3,4)$. WNV reproduces itself efficiently in a number of species of wild birds, where there is sufficient virus in the blood to infect mosquitoes (5). Many animal species, including mammals, are susceptible to natural WNV infection, but their role in transmission is unknown. Horses and humans appear to be 'dead-end' hosts and are not reservoirs for the virus.

In Canada, WNV appears to follow an annual cycle typical of other viruses that also primarily infect mosquitoes, birds and, incidentally, humans (5). In the spring, the virus first becomes active, either through the return of WNVinfected migratory birds or when dormant adult mosquitoes that were infected the previous year become active. Local mosquitoes become infected by feeding on the newly returned infected birds. Previously infected mosquitoes can also infect susceptible birds. Each infected bird can then infect several more mosquitoes. During the spring and summer, this cycle of transmission of WNV between birds and bird-feeding mosquitoes results in a major increase in the population of infected birds and mosquitoes. Of note, most of the mosquito species that feed on humans and other mammals generally do not feed on birds. By late summer, however, the species of mosquito that feeds on both birds and mammals reach their peak of annual activity and set the stage for transmission of WNV infection to humans. Review of the annual cases of WNV in Canada shows that the period of greatest risk of infection for people, horses and other mammals is in late summer and early fall (6).

Since its arrival in Canada, WNV has spread from Ontario and Quebec to the west, with predominant activity in 2007 being in Saskatchewan, Manitoba and Alberta (6). The Web site of the Public Health Agency of Canada provides regular updates on WNV activity by province (6). The Atlantic and northern regions of Canada have been relatively spared, likely due to differing species of mosquitoes. However, climate change in Canada may lead to an expansion in the geographical range and abundance of mosquitoes that can carry WNV, and an increase in WNV transmission to humans in areas where this is now low.

Currently, neither transfusion of blood products nor organ transplantation pose a serious risk for WNV transmission. Since 2003, when Héma-Québec and Canadian Blood Services started screening all blood products used in Canada, there have been no documented cases of WNV transmission via blood products. Organ, cell and tissue donors are also screened. Thus, patients and families can be reassured that blood and blood products in Canada are safe from WNV, even during the height of the mosquito and WNV season.

Symptomatic disease continues to be predominantly seen in adults, with smaller numbers reported in children (encephalitis, meningitis, tremor and flaccid paralysis) (7). The first case report (8) of intrauterine WNV transmission in 2002, involved an infant who had bilateral chorioretinitis and severe cystic destruction of cerebral tissue (temporal and occipital areas). Subsequently, there have been case reports $(7,9)$ of WNV infection in pregnancy, with no adverse outcome in the fetus or infant. Furthermore, more recent evidence suggests that the risk to pregnant women for transmission to the fetus with an adverse outcome is not high. A review (10) of cord blood in 2003/2004 at one hospital in Colorado showed that $4 \%$ of 566 pregnant women had immunoglobulin $G$ antibodies to WNV. None had immunoglobulin $\mathrm{M}$ antibodies to WNV (10). There were no significant differences in the outcomes of infants born to seropositive versus seronegative mothers. A probable transmission via breast milk has also been reported, albeit without adverse outcomes (11). These data suggest that in WNV outbreaks, infection of pregnant women is not uncommon, but infant adverse events are rare. These data should be reassuring to pregnant women, although larger studies are needed.

Diagnostic serology for WNV is available through most provincial laboratories.

Given that there is no available human vaccine for WNV, prevention of infection in humans is centred on diminishing risks of mosquito bites (Table 1). Health Canada's Committee to Advise on Tropical Medicine and Travel provides additional advice on protective measures to prevent arthropod bites (12). 


\section{TABLE 1}

Measures to decrease risk of West Nile virus infection

- Reduction of the mosquito population

- Limit standing water around the home because these provide breeding grounds for mosquitoes. In certain jurisdictions, more aggressive mosquito control measures may be employed by public health

- Reduction of exposure to mosquitoes

- Avoid infested areas, limit outdoor time when there is high mosquito activity, screen windows and doors

- Use of barrier to protect skin

- Use mosquito nets on carriages and strollers. Wear long, light coloured pants and long-sleeved tops

- Use insect repellents to discourage mosquitoes from biting (12)

Reproduced and adapted from references 1 and 12

\section{REFERENCES}

1. Canadian Paediatric Society, Infectious Diseases and Immunization Committee [Principal author: D Moore]. West Nile Virus Mosquitoes no longer just an annoyance! Paediatr Child Health 2003;8:267-70.

2. Canadian Paediatric Society, Infectious Diseases and Immunization Committee [Principal author: D Moore]. West Nile Virus -

Preparing for Summer 2004. Paediatr Child Health 2004;9:301-2.
3. Public Health Agency of Canada. West Nile virus and animals. $<$ http://www.phac-aspc.gc.ca/wn-no/anim-eng.php > (Version current at May 2, 2008).

4. Canadian Food Inspection Agency. West Nile virus. <http://www.inspection.gc.ca/english/anima/heasan/disemala/ wnvvno/wnvfse.shtml> (Version current at May 2, 2008).

5. University of Saskatchewan. West Nile virus. $<$ http://wildlife1.usask.ca/wildlife_health_topics/arbovirus/ arbown.php $>$ (Version current at May 2, 2008).

6. Public Health Agency of Canada. West Nile virus Monitor. $<$ http://www.phac-aspc.gc.ca/wnv-vwn/index-eng.php> (Version current at May 2, 2008).

7. Hayes EB, O'Leary DR. West Nile virus infection: A pediatric perspective. Pediatrics 2004;113:1375-81.

8. Alpert SG, Fergerson J, Noël LP. Intrauterine West Nile virus: Ocular and systemic findings. Am J Opthalmol 2003;136:733-5.

9. Skupski DW, Eglinton GS, Fine AD, Hayes EB, O'Leary DR. West Nile virus during pregnancy: A case study of early second trimester maternal infection. Fetal Diagn Ther 2006;21:293-5.

10. Paisley JE, Hinckley AF, O'Leary DR, et al. West Nile virus infection among pregnant women in a Northern Colorado community, 2003 to 2004. Pediatrics 2005;117:814-20.

11. Centers for Disease Control and Prevention (CDC). Possible West Nile virus transmission to an infant through breast-feeding Michigan, 2002. MMWR Morb Mortal Wkly Rep 2002;51:877-8.

12. Canada Communicable Disease Report. Statement on Personal Protective Measures to Prevent Arthropod Bites. $<$ http://www.phac-aspc.gc.ca/publicat/ccdr-rmtc/05vol31/ asc-dcc-4/index.html> (Version current at May 2, 2008).

\section{INFECTIOUS DISEASES AND IMMUNIZATION COMMITTEE}

Members: Drs Robert Bortolussi, IWK Health Centre, Halifax, Nova Scotia (chair); Dorothy L Moore, The Montreal Children's Hospital, Montreal, Quebec; Joan L Robinson, University of Alberta, Edmonton, Alberta; Élisabeth Rousseau-Harsany, Sainte-Justine UHC, Montreal, Quebec (board representative); Lindy M Samson, Children's Hospital of Eastern Ontario, Ottawa, Ontario

Consultant: Dr Noni E MacDonald, IWK Health Centre, Halifax, Nova Scotia

Liaisons: Drs Upton D Allen, The Hospital for Sick Children, Toronto, Ontario (Canadian Pediatric AIDS Research Group); Scott A Halperin, IWK Health Centre, Halifax, Nova Scotia (Immunization Program, ACTive); Charles PS Hui, Children's Hospital of Eastern Ontario, Ottawa, Ontario (Health Canada, Committee to Advise on Tropical Medicine and Travel); Larry Pickering, Elk Grove Village, Illinois, USA (American Academy of Pediatrics, Red Book Editor and ex-officio member of the Committee on Infectious Diseases); Marina I Salvadori, Children's Hospital of Western Ontario, Ottawa, Ontario (Health Canada, National Advisory Committee on Immunization)

Principal author: Dr Noni E MacDonald, IWK Health Centre, Halifax, Nova Scotia

The recommendations in this statement do not indicate an exclusive course of treatment or procedure to be followed. Variations, taking into account individual circumstances, may be appropriate.

This article also appears in the May/June 2008 issue of Paediatrics $\mathbb{E}$ Child Health. 


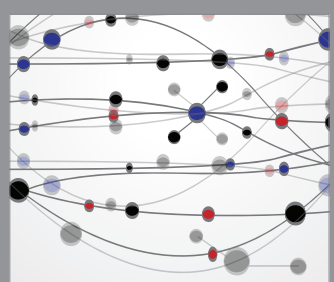

The Scientific World Journal
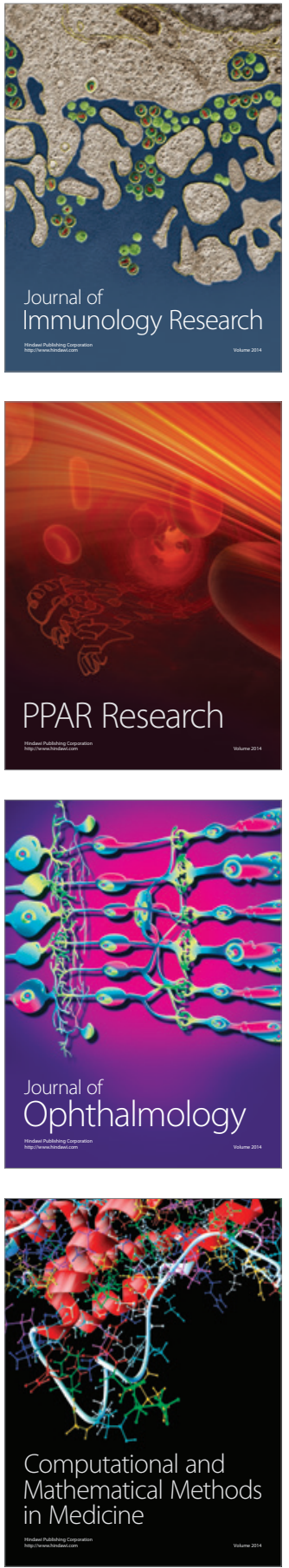

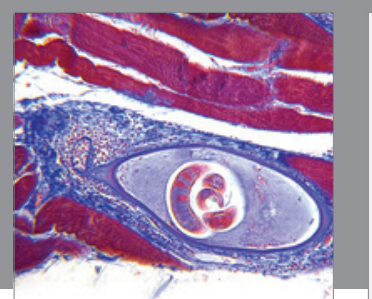

Gastroenterology Research and Practice

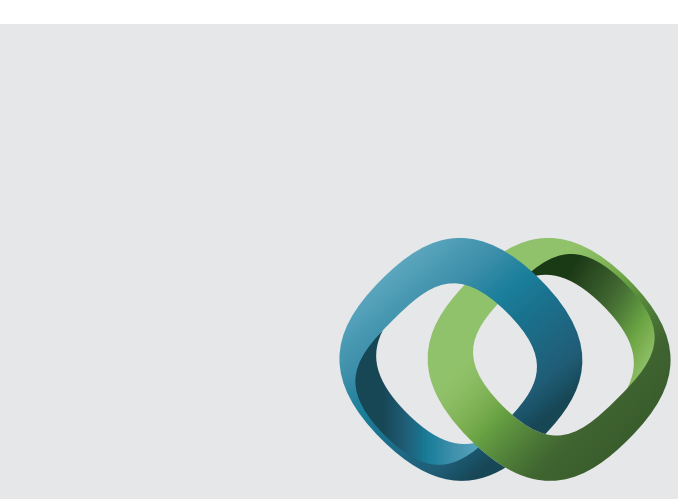

\section{Hindawi}

Submit your manuscripts at

http://www.hindawi.com
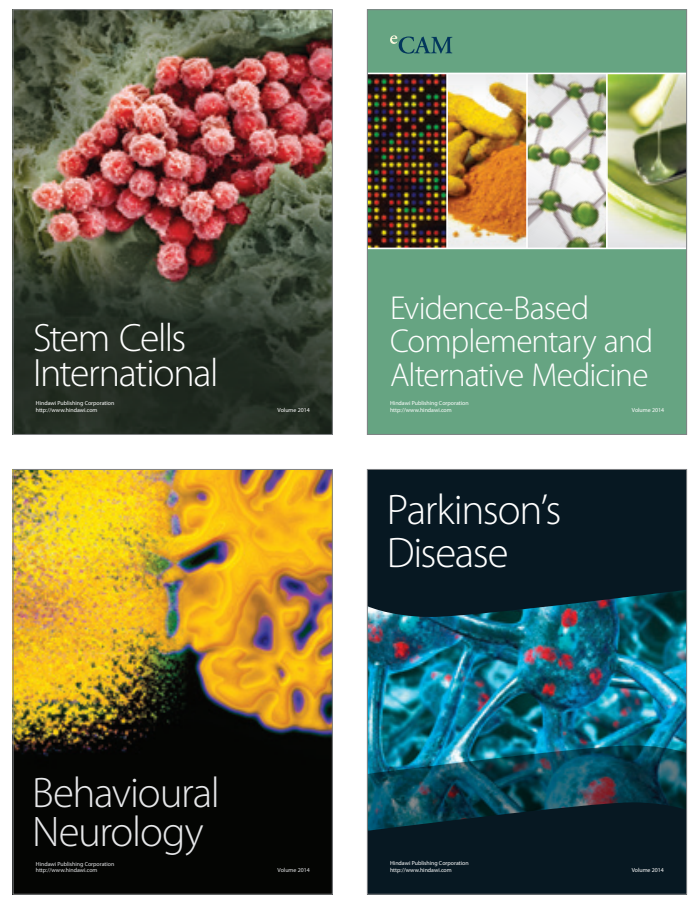
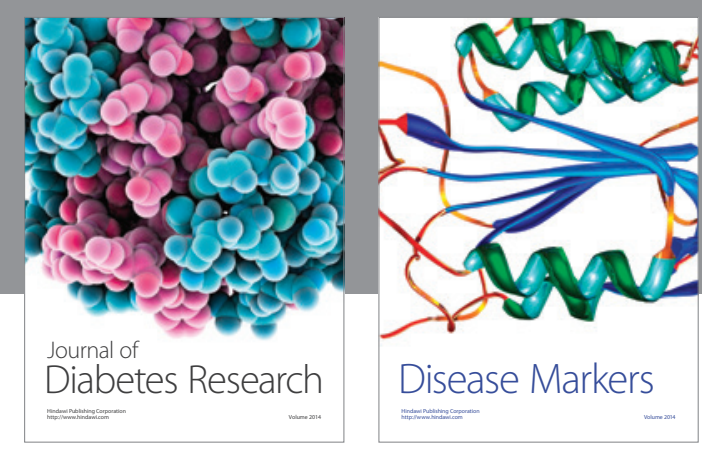

Disease Markers
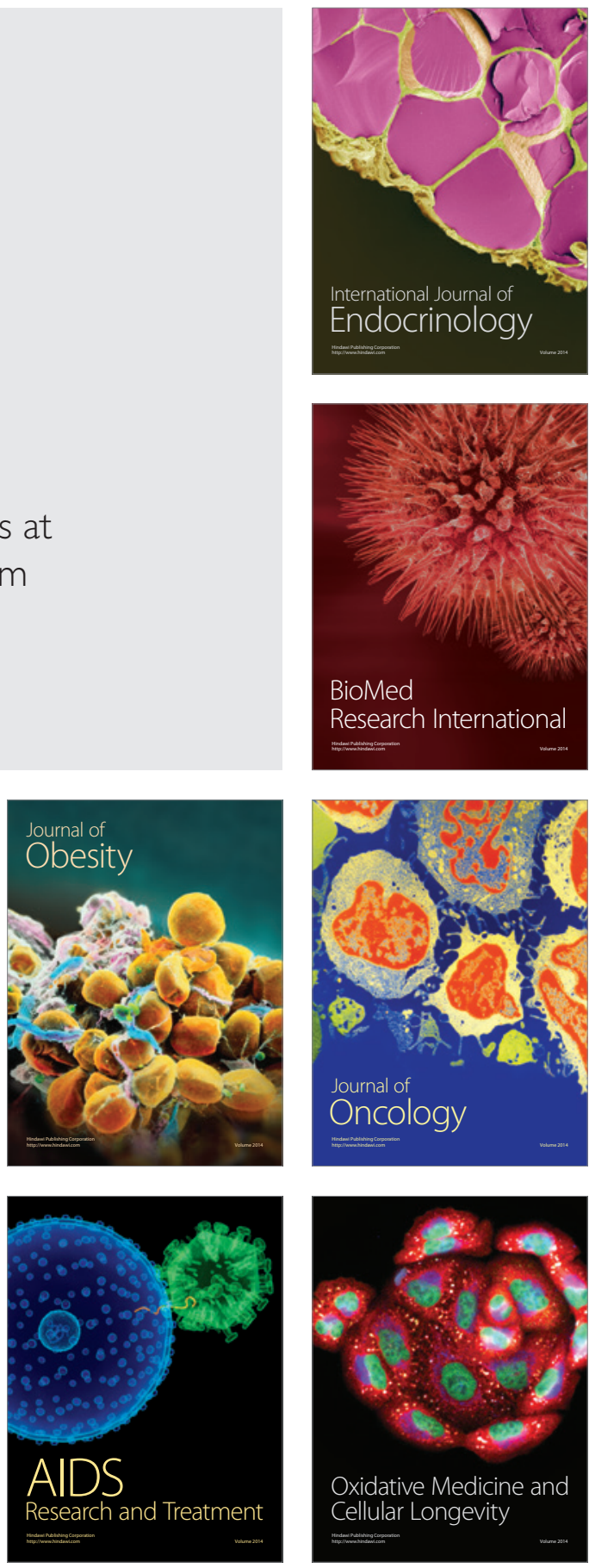